Скопень М. М., к.е.н., доцент Красавцева Л. Ю., к.н.держ.упр. Київький державний коледж туризму та готельного господарства м. Київ, Украӥна

DOI: https://doi.org/10.30525/978-9934-26-064-3-38

\title{
ОДИН ІЗ ПІДХОДІВ ДО ОПТИМІЗАЦІї ВАРТОСТІ ПОСЛУГ ГОСТИННОСТІ
}

Вивчення формування вартості послуг гостинності свідчить про те, що в багатьох літературних джерелах, які присвячені маркетинговим дослідженням, достатньо добре розглянуто загальні принципи ціноутворення з урахуванням таких основних факторів, як витрати та цільовий прибуток, ціноутворення конкурентів та попит на надавані послуги [1; 2]. Відоме також джерело [3], яке пропонує методику оптимізації вартості путівок для підприємств санаторно-курортної сфери. Однак, як показує аналітичний огляд, жодне видання не дає чіткої відповіді, 
яким чином застосувати технологію комплексного підходу, тобто одночасного урахування вказаних вище факторів 3 їх оптимізацією. Саме ця технологія і пропонується авторами нижче для розгляду.

Для розрахунку оптимальної вартості послуг гостинності зручно на платформі застосунку Excel використовувати економіко-математичні та графічні методи комплексного аналізу еластичності попиту, тобто чутливості клієнтів до зміни цін на послуги, та розрахунку витрат з пошуком точки беззбитковості підприємства, а також з урахуванням максимізації прибутку.

Розглянемо дану технологію на прикладі готелю, подальший розвиток господарської діяльності якого обумовлює вивчення чутливості клієнтів, з метою формування оптимальної вартості розміщення та забезпечувало зростання їх кількості і одночасно давала 6 можливість максимізувати дохід та прибуток від реалізації послуг.

Спочатку обчислюється на визначений рік середня ціна (наприклад, стійки, тобто для разових клієнтів) з урахуванням різних категорій номерів, приріст загальних витрат, приріст кількості обслугованих клієнтів, а також середнє зменшення при цьому вартості послуги. Наприклад, розрахунки показали, що кількість обслугованих туристів складає 40,3 тис. осіб/рік, середня ціна стійки - 985 грн, а загальні витрати - 22064 тис. грн. Окрім того, базисні прирости кількості клієнтів становили 8,1\% або 3,26 тис. осіб, загальних витрат - 13,1\% або 2891 тис. грн, а базисне зменшення вартості проживання склало 6,9\% або 68 грн (табл. 1).

Отже, можна припустити, що при середній ціні стійки 985 грн в готелі може бути розміщено за рік 40,3 тис. осіб, а при зменшенні вартості проживання на -6,9\% попит зростає на 8,1\%. При цьому приріст загальних витрат складатиме 13,1\%.

Перевіряється чутливість клієнтів на вартість проживання в готелі, тобто визначається еластичність попиту (табл. 1). Тут необхідно врахувати ту обставину, що зменшення ціни на 68 грн збільшує попит на послуги розміщення на 3,26 тис. осіб. Для 
наглядності, при розрахунках чутливості клієнтів, зробимо обчислення для 10-ти варіантів змін у попиті та вартості проживання.

Таблиця 1

Оптимізація вартості проживання з урахуванням еластичності попиту, витрат, доходів та прибутку готелю

\begin{tabular}{|c|c|c|c|c|c|c|c|c|}
\hline № & 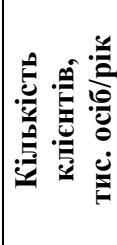 & 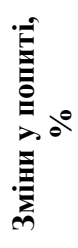 & 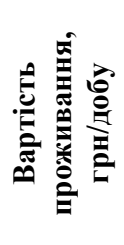 & 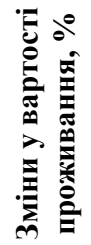 & 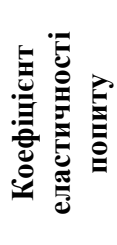 & 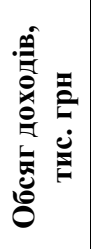 & 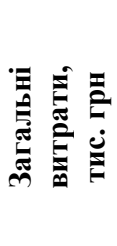 & 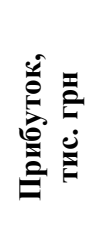 \\
\hline 1 & 40,300 & - & 985 & - & - & 39696 & 22064 & 17632 \\
\hline 2 & 43,564 & $8,1 \%$ & 917 & $6,9 \%$ & 1,2 & 39948 & 24955 & 14993 \\
\hline 3 & 46,829 & $7,5 \%$ & 849 & $7,4 \%$ & 1,0 & 39757 & 27845 & 11912 \\
\hline 4 & 50,093 & $7,0 \%$ & 781 & $8,0 \%$ & 0,9 & 39123 & 30736 & 8387 \\
\hline 5 & 53,357 & $6,5 \%$ & 713 & $8,7 \%$ & 0,7 & 38044 & 33627 & 4417 \\
\hline 6 & 56,622 & $6,1 \%$ & 645 & $9,5 \%$ & 0,6 & 36521 & 36521 & 0 \\
\hline 7 & 59,886 & $5,8 \%$ & 577 & $10,5 \%$ & 0,5 & 34554 & 39409 & -4855 \\
\hline 8 & 63,150 & $5,5 \%$ & 509 & $11,8 \%$ & 0,5 & 32143 & 42300 & -10157 \\
\hline 9 & 66,414 & $5,2 \%$ & 441 & $13,4 \%$ & 0,4 & 29289 & 45190 & -15901 \\
\hline 10 & 69,679 & $4,9 \%$ & 373 & $15,4 \%$ & 0,3 & 25990 & 48081 & -22091 \\
\hline
\end{tabular}

Джерело: розроблено авторами

Визначення зміни в попиті по $j$-му варіанту розрахунку $\left(3 p_{j}\right)$ проводиться за формулою, яка визначає ланцюгові темпи приросту:

$$
3 \mathrm{p}_{j}=\frac{\mathrm{K}_{j}-\mathrm{K}_{j-1}}{\mathrm{~K}_{j-1}} * 100 \%,
$$

де $\mathrm{K}_{j}$ - кількість клієнтів по $j$-му варіанту розрахунку;

$\mathrm{K}_{j-1}$ - кількість клієнтів у попередньому варіанті розрахунку.

Визначення зміни у вартості проживання по $j$-му варіанту розрахунку (Зц्) здійснюється за формулою: 


$$
3 ц_{j}=A B S\left(\frac{\bigsqcup_{j}-\bigsqcup_{j-1}}{\bigsqcup_{j-1}}\right) * 100 \%,
$$

де $\bigsqcup_{j}-$ вартість проживання по $j$-му варіанту розрахунку;

$\bigsqcup_{j-1}$ - вартість проживання у попередньому варіанті розрахунку.

Еластичність попиту визначається як відношення змін у попиті до змін в ціні.

Таким чином в нашому прикладі розрахунки показують, що найбільш прийнятний коефіцієнт еластичності попиту для готелю є 1,2 (табл. 1) з точки зору отримання максимального обсягу доходів, тобто 39948 тис. грн. В даному випадку вартість послуги розміщення становитиме 917 грн.

Однак отримання максимального доходу готелем від надання послуг гостинності 43,564 тис. осіб/рік за ціною 917 грн ще не забезпечує отримання максимального прибутку, оскільки при збільшенні числа клієнтів швидко зростають витрати підприємства.

Далі здійснюється аналіз беззбитковості як орієнтира у визначені мінімальної вартості проживання, яка збезпечує повне відшкодування витрат (рис. 1).

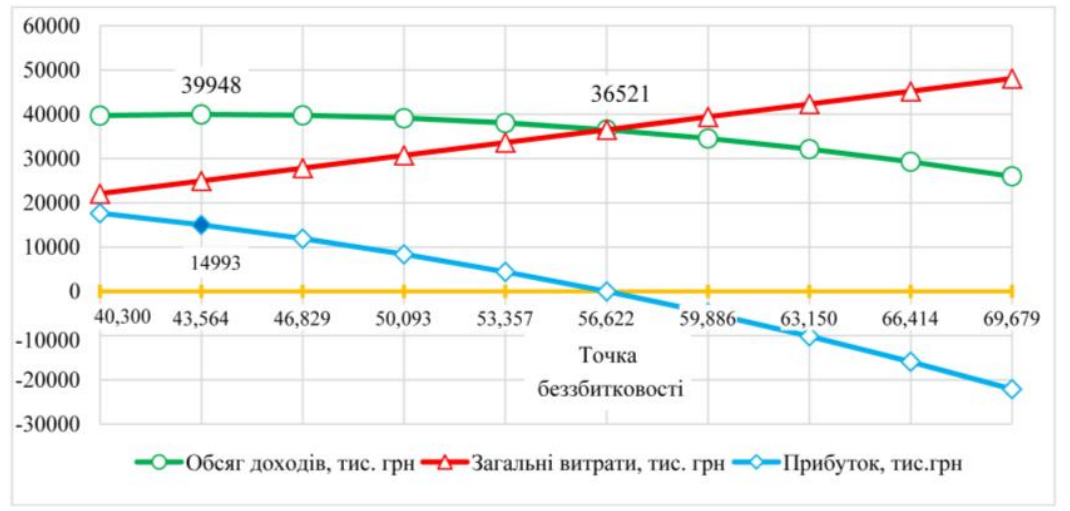

Рис. 1. Визначення точки беззбитковості

та оптимальної вартості проживання кліснтів готелю

Джерело: розроблено авторами 
Аналіз беззбитковості потребує знаходження точки беззбитковості за формулою:

$$
\mathrm{T}_{\mathrm{b}}=\frac{\text { Д }}{Ц} \text { при } \quad \Pi=Д-\mathrm{B}=0,
$$

де $\mathrm{T}_{\mathrm{5}}$ - точка беззбитковості;

Д - дохід (виручка) від реалізації послуг;

Ц - вартість послуги розміщення;

П - прибуток;

В - витрати.

В нашому випадку $\mathrm{T}_{5}$ - це та кількість клієнтів, при розміщенні яких буде повне покриття витрат готелю. При цьому доходи будуть дорівнювати загальним витратам, а прибуток дорівнюватиме нуль. В наведеному прикладі для покриття витрат необхідно надати послуги розміщення 56,622 тис.осіб за вартістю проживання 645 грн (табл. 1). Розміщення більшої кількості клієнтів призведе до збитків оскількі суттєво зростають загальні витрати готелю.

Висновок. Розрахунок оптимальної вартості послуг розміщення показав вибір для готелю наступних рівнів цін:

1 рівень - 645 грн, який забезпечить повне відшкодування витрат, залучить нових клієнтів, але не забезпечить прибутку;

2 рівень - 917 грн, який забезпечить максимальний дохід та прийнятний рівень прибутку (14993 тис. грн);

3 рівень - 985 грн, який забезпечить максимальне значення прибутку (17632 тис. грн) але $\epsilon$ ризик зменшення кількості клієнтів.

Безумовно, для готелю є бажаним третій рівень цін (985 грн), який забезпечить максимальний рівень прибутку. Однак при встановлені такої вартості проживання $є$ ризик зменшення кількості клієнтів, а також зростання ризику досягнення максимізації прибутку. Отже, більш прийнятним для готелю $є$ другий рівень цін (917 грн). 


\section{Література:}

1. Агафонова Л.Г., Агафонова О.С. Туризм, готельний та ресторанний бізнес: ціноутворення, конкуренція, державне регулювання : навчальний посібник. Київ : Знання України, 2002. 358 с.

2. Мальська М.П., Мандюк Н.Л. Основи маркетингу у туризмі : підручник. Київ : Центр учбової літератури, 2016. 336 с.

3. Миронов Ю.Б., Новицька-Колодіна А.О. Методика оптимізації цінової політики підприємств рекреаційного туризму. Молодь і ринок. 2005. № 1 (11). C.106-109. 